\title{
Toko Tani Indonesia: National Program for Shortening Rice Supply Chain
}

\author{
Iwan Setiajie Anugrah \\ Indonesian Center for Agricultural Socioeconomic and \\ Policy Studies \\ Ministry of Agriculture \\ Bogor, Indonesia \\ iwansetiajie@yahoo.com
}

\author{
Sri Wahyuni \\ Indonesian Center for Agricultural Socioeconomic and \\ Policy Studies, \\ Ministry of Agriculture \\ Bogor, Indonesia \\ maloleyayuk@yahoo.com
}

\begin{abstract}
One of The Indonesian government effort to achieve the community food security, is through Toko Tani Indonesia (TTI) or the Indonesian Farmers Shop which is shorten the supply chain, to achieve stable supply and price of basic food. To get maximum performance, indicators of achievement have been designed by the Food Security Agency Ministry of Agriculture. To know the efficiency of the supply chain, effects the program to supply and price stability, access of people to the program as well as strategy for better performance of TTI, research on the implementation of the program were conducted during 2018 in Banten, West and Central Java Provinces as well as the Capital City of Jakarta with total samples of 47 TTI. The information were collected from secondary and primary data, than analyzed qualitatively. This paper presents the performance of TTI in: (1) The efficiency in Supply Chain ; (2) Stability of the supply and Price; (3) Providing easy access (4) Strategy for better TTI's performance. The results show that: (1)The TTI program had definitely success in shortening the supply chain. (2) The contribution of TTI rice had not influence the stabilization of supply and market price yet and (3) consumers had no easy access yet to have TTI rice. (4) Strategy to improve TTI's performance includes improve the internal management of actors in TTI namely, support the funding compensation in order LUPM can continue to exist, obligate LUPM to supply the rice to TTI periodically, design the criteria of the consumer and Developed more TTI in wider areas.
\end{abstract}

\section{Keywords - TTI, supply chain, rice and actors}

\section{INTRODUCTION}

The fact that frequent fluctuations of prices on food commodities and its long supply chain potentially caused social unrest and inflation, the Indonesian government is implementing a program called the Community Food Business Development Activities or Program Pengembangan Usaha Pangan Masyarakat (PUPM) through the Indonesian Farmers Shop or Toko Tani Indonesia (TTI). This activities supported by Decree No. 06/KPTS / KN.010/K/02/2016 [1] on the General Guidelines for the PUPM and act of Minister of Agriculture No.06/KPTS/RC.110/J/01/2017 for the implementation of PUPM [2]. The goals of the PUPM are: (1) To absorb national agricultural products at feasible price and benefited the farmers, especially for basic and strategic food such as rice, chilli and shallot; (2) Support the stabilization of the food supply and prices; and (3) Provide easy access for consumers on the quantity and quality of food commodities at reasonable prices. This program was implemented since 2016 (500 TTI) covered 32 provinces, another 7 provinces in 2017 (399 TTI) and additional TTI in 2018, therefore the total TTI are 1.156

To execute this program, in 2016 a capital funds of IDR 200 million/year was given to each farmer group (kelompok tani) and/or the union of farmers group (gapoktan). Kelompok tani (Poktan) and gapoktan who received The PUPM program called LUPM (Lembaga Usaha Pangan Masyarakat). The money (IDR 160 million) must be used to purchase grain from the gapoktan's member and surrounding farmers at higher price, above the highest retail price or harga eceran tertinggi (HET) regulated by the government. Money of IDR 40 million is for operational funds. At this step LUPM called at growth TTI or TTI penumbuhan, then continues to develop in the second year as TTI under guidence or TTI pembinaan which is only receive the operational fund and in the third year LUPM is expected to be independent and no funding any more.

Since 2017 , for some reason the IDR160 million given to LUPM become only IDR100 million. There was a regulation that rice supplied to TTI must be into premium quality in a package of $5 \mathrm{~kg}$ rice with the TTI logo/symbolic. For the HET IDR 9,450, LUPM is obliged to supply 38 tons of rice, HET IDR 9,950 of 34 tons and HET of IDR 10,250 of 30 tons rice. Specifically, for LUPM Jabodetabek suppliers are obligated to supply TTI/TTIC in the Jabodetabek region of 10 tons of rice and 25 tons in their own province.

The rice produced by LUPM must be sold to TTI with predetermined prices and then TTI must also sold the rice to consumers with determined price to be cheaper than HET. The Highest Retail Price in TII (2018) IDR 8,800/kg, for regions where the retail price of rice is below IDR $8,800 / \mathrm{kg}$ and the TTI rice prices at maximum of $10 \%$ below market prices (bsed on price panel data). The volume, quality and price of rice from LUPM to TTI were monitored by a Pendamping (Assistant). The LUPM, TTI and Assistant were selected based on certain criteria, 14, 12 and 7 criteria respectively as outlined in the Technical Guidelines for Activities [2].

As the concepts and techniques have been improved in 2018, a research to evaluate is needed to determine the achievement of the program. This paper presented the results of a research on TTI performance, especially for rice. The objectives of the research is to get information on the performance of TTI rice in: A) The efficiency of TTI in Supply Chain; B) Maintaining the stabilization of rice supply 
and price; C) Providing Easy Access and D) To formulate strategy and policy for better TTI design to get maximum achievement.

\section{METHODOLOGY}

\section{A. Locations and Respondents}

Provinces of Banten, West and Central Java as well as Jakarta City were chosen according to some considerations such as the level of LUPM and the TTI affordability of location. The total respondents were 47 TTI, consist of TTI Center (TTIC=1), TTI Center in District level (TTIC-D = 9) and local TTI (37).

\section{B. Data and Methods of Analysis}

The data were collected during 2019, consist of secondary data obtained from report of various institutions related to PUPM/LUPM and TTI activities. The primary data was collected from TTI owner through individual interviews base on structure questionnaire. Data were analyzed qualitatively [3] and presented describtively according to each objective. Objective 1 measured by comparing the supply chain of the TTI network with the local marketing chain. Objective 2 analysed by comparing the sales price of TTI rice to market prices at the consumer level. Objective 3 measured by inter-time of rice volume supply from LUPM to TTI as have been designed compare to the community needs [4]. Objective 4, will be formulated based on the results and finding from the survey.

\section{RESULTS}

There are certain mechanism for determining/selecting the actors of the program (farmers, LUPM, TTI and Pendamping). Farmers must be the member of the poktan or gapoktan, a number of 13 criteria for LUPM, 10 criteria and 7 criteria respectively for TTI and the Assistant. It was found only one out of 13 criteria for LUPM that cannot be fulfilled namely own dryer, therefore the LUPM were using the natural dryer (The sun rise). Farmer perceived this technique is not considered a problem since dryer requires more cost than natural dryer. LUPM Sari Tani in Kerawang Regency, West Java, reported that the difference in the cost of drying with labor and the sun rise compared to a dryer plus blower was IDR 5 compared to IDR 150 to produce a $\mathrm{kg}$ of grain which means 30 times more expensive. This fact caused the LUPM choosed dryer and blowers only during the hard rainy season.

Other example was found in, LUPM Mekar Tani that also have a dryer but used it only when the weather is raining because the operational costs reach Rp280 / kg [5]. For TTI, only 3 criteria out of 10 that cannot be implemented such as had experience on trading for 1-2 years, had trade business licenses and records the volume of rice received and sold along the year. These criterias was not influence the TTI performance since all TTI has no difficulties in selling the rice. TTI not done the recording because they assumed the task was the responsibility of the Assistant. The TTI perceived that their responsibility is only to pay for the rice received, so once the payment had been paid off, the notes and or the receipts are deemed unnecessary and disposed of.
For the assistant, there are 4 out of 7 criteria that had not yet been implemented: 1) The assistant domicile is not always based in the LUPM; 2) The assistant has a dual duty assignment (as Extension workers); 3) Not all assistant had opportunity to participate the socialization of the program and 4) The assistant not submit the report on time. These four criterias are closely related considering that an Assistant were generally an agricultural extension officer who already has a certain work area or wilayah kerja. Other reason is that an assistant only receive IDR500 000 for doing the job. Especially in 2018, was no salary or incentives anymore for the Assistant to do the job, therefore no monitoring and evaluation anymore, however some agencies such as the DKI Jakarta Food Security Department [6] allocate special funds for the Assistant. Under these conditions, the performance of TTI is as the following describtion.

\section{A. The Efficiency of TTI on Rice Supply Chain}

Efficient is a way to achieve a goal with minimal use of resources but maximum results, resources are processed wisely and economically so the money, time and energy are not wasted. Efficiency is the existing of time, energy, or costs used for an activity [7]. For producing rice, there is no different time and energy between TTI and market rice. Related to cost (economically), it is very clear that there is a significant difference because TTI is a subsidy program with a certain requirement (rice is medium level and packed in plastic with a special TTI logo. The following describtion is the cost analysis to produce a $\mathrm{kg}$ of TTI rice Mekar Tani (Table I).

TABLE I. THE PROCESS AND PRICE TO PRODUCE TTI RICE

\begin{tabular}{|c|l|r|l|}
\hline No. & \multicolumn{1}{|c|}{ Activities } & \multicolumn{1}{|c|}{$\begin{array}{l}\text { Price/ } \\
\text { Wage } \\
\text { (IDR/kg) }\end{array}$} & \\
\hline 1 & Grain & 5,500 & Farmers' price IDR 5,000, plus 10\% \\
\hline 2 & $\begin{array}{l}\text { Transport grain } \\
\text { to RMU }\end{array}$ & 100 & \\
\hline 3 & $\begin{array}{l}\text { Drying the } \\
\text { grain }\end{array}$ & $60-90$ & $\begin{array}{l}\text { One day drying IDR60/kg, more } \\
\text { IDR90/kg }\end{array}$ \\
\hline 4 & Milling & 80 & Per kg rice \\
\hline 5 & Mechine & 150 & Per kg rice \\
\hline 6 & Dryer 1 & 280 & Only during the bad wheather \\
\hline 7 & Packing & 10 & IDR 12,000/ /240 sheet/5kg \\
\hline 8 & $\begin{array}{l}\text { Transport } \\
\text { from } \\
\text { LUPM-TTI }\end{array}$ & 370 & IDR 3,500,000/9.5 ton \\
\hline & Total & 6580 & \\
\hline
\end{tabular}

Based on Table I, the price to produce one $\mathrm{kg}$ of TTI rice was IDR6 580, therefore by selling at TTI as IDR 7,500 In 2016 the LUPM alreaday benefit IDR1 920 while in 2017 IDR 1,420. In traditional market chain the rice price is IDR 10,500 to IDR 11,000 means gave benefit to the LUPM almost twise compare with TTI rice eventhough in the supply chain of rice in Indonesian traditional market consist of seven actors (Scheme 1). 


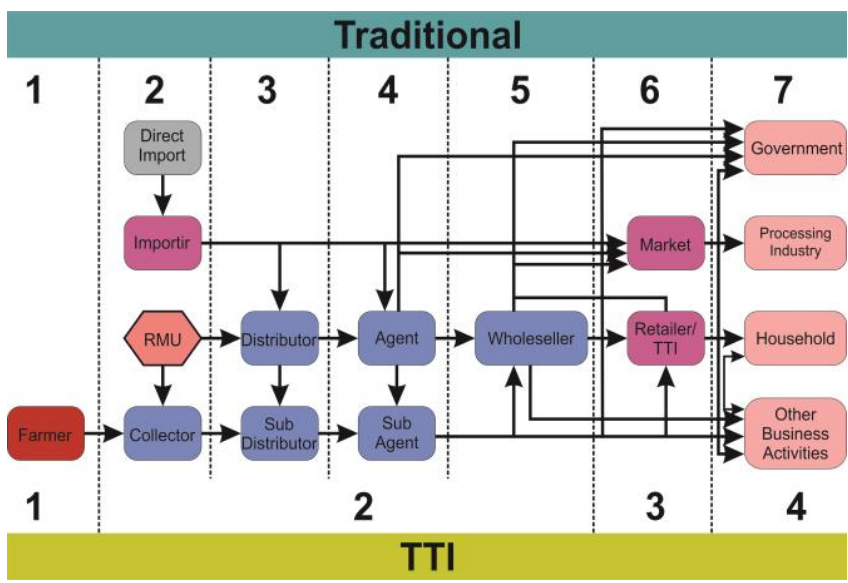

Scheme 1. Rice Supply Chain in Traditional Market Compare to TTI

The supply chain through TTI only 4 (four) actors: 1) Farmers as producers: 2) Gapoktan / LUPM as buyers of the grain, and processing as medium rice as well as the rice suppliers to TTI; and 3) TTI as a retailer for rice to consumers and 4 consumers. The scheme are clearly showed that TTI program had shorten the supply chain of rice from 7 to 4 actors, the decrease of the actors is caused by triple function of LUPM.

\section{B. TTI's Performance in Maintaining Stabilization on Supply and Price of Rice}

Shortening the supply chain is expected to reduce the price of production inputs but there are other factors which affect price stabilization including the season that affect the rice supply. Results during three years showed that there were similar trend on the peak of rice harvest pattern/year (Figure 1).

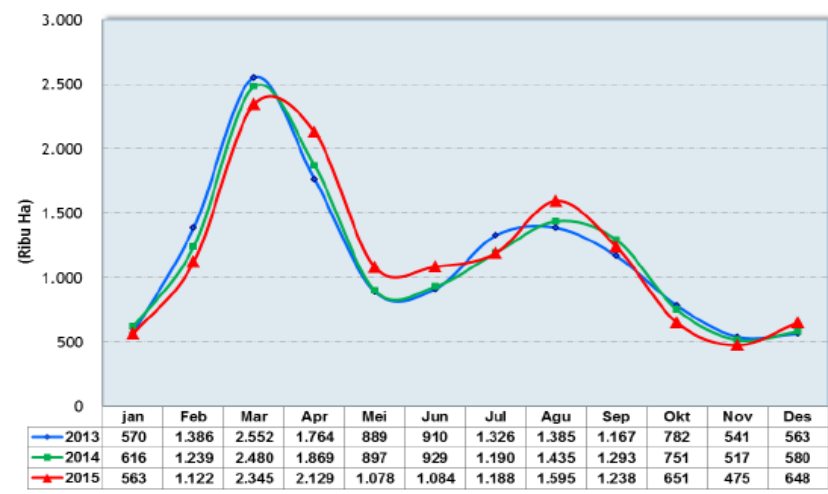

Fig 1. Rice harvest patterns in Indonesia (2013 - 2015)

There are two peak rice harvest pattern/year, the first and the highest production is during March and April, second major harvest was during August and September (gadu) season, followed by non-harvest (famine season) during October to February. Other reason, is all LUPM fulfill their responsibility to supply the rice target as obligated/year to TTI as soon as they could. The reason in there was no obligation of the routinity supply to TTI, therefore during the harvest season LUPM sell the rest of their production to market which give twice benefit. As the consequence consumers could not get the rice as much as and on the time they need, therefore the contribution of supply from TTI still could not influence the stabilization of supply and market price as in (Figure 2) in 2017 the price of TTI rice was IDR 9450 while in traditional market IDR 10,700 to IDR 11,000 and even the price of both rice were increased during 2018.

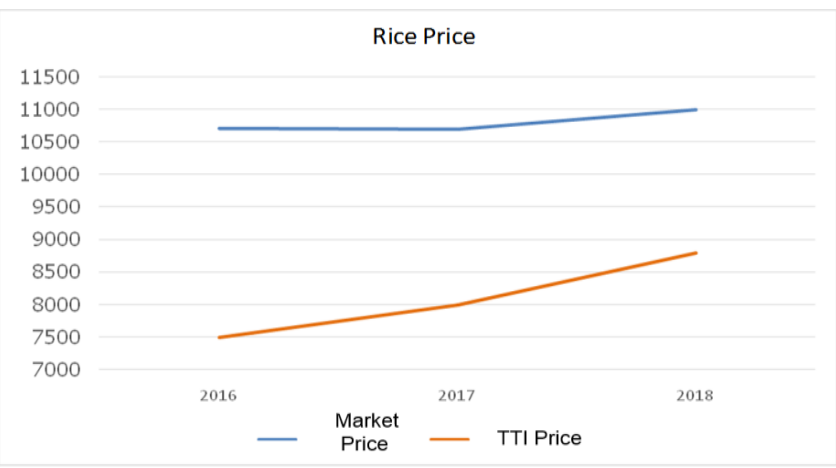

Fig 2. The Comparison of Medium Rice Price at Consumers Level between TTI and Traditional market

\section{The Performance of TTI in Providing Easy Access on Rice}

The indicator of TTI performance in providing easy access on rice are, LUPM ability to supply rice to TTI in accordance with a predetermined volume sustainably and the location of TTI is strategic as well as accessible by the community. It was found that all LUPM are able to supply rice to TTI according to the volumes that have been determined and rice at TTI is also always sold out, even many consumers do not get rice because of the limited volume. Some efforts have been taken by TTI, for example by limiting the amount of rice purchased, which is a maximum of $10 \mathrm{~kg} / \mathrm{head}$ of family. Other ways to limit the purchases was, the consumers must bring the family card to ensure that rice is for the family consumption, not for sale. The consumers varies from household consumers, $u d u g$ rice traders, catering business and Tegal food stalls. They are permitted to buy since the rice were sold as ready food for consumption.

TABLE II. CONTRIBUTION OF TTI RICE ON NASIONAL NEEDS

\begin{tabular}{|c|c|c|c|c|c|}
\hline Year & $\begin{array}{c}\text { Total } \\
\text { number } \\
\text { of } \\
\text { LUPM }\end{array}$ & $\begin{array}{c}\text { 1) } \\
\text { LuPMM } \\
\text { rice } \\
\text { supply } \\
\text { Ton/LU } \\
\text { PM/year } \\
\mathbf{1 )}\end{array}$ & $\begin{array}{c}\text { Total } \\
\text { volume } \\
\text { of } \\
\text { LUPM } \\
\text { supply } \\
\text { Ton/LU } \\
\text { PM/year } \\
\text { 1) }\end{array}$ & $\begin{array}{c}\text { Rice } \\
\text { consump- } \\
\text { tion } \\
\text { /cap/year } \\
\text { (000 ton) }\end{array}$ & $\begin{array}{c}\text { 2) } \\
\text { Propor- } \\
\text { tion of } \\
\text { LUPM } \\
\text { supply } \\
\text { (\%) }\end{array}$ \\
\hline 2016 & 500 & 45 & 22,5 & 30.690 & 0,073 \\
\hline 2017 & 899 & 45 & 40,5 & 29.190 & 0,139 \\
\hline 2018 & 1.156 & 35 & 40,5 & 29.570 & 0,137 \\
\hline
\end{tabular}

Numbers of TTI were increased (Table II) however data simulation based on the LUPM supply obligation to TTI, then proxy against the amount of rice consumption per capita per year (total population) the proportion of rice supply from LUPM in 2016 only $0.073 \%$, in 2017 and 2018 was 0.139 and $0.137 \%$ respectively. The percentage of TTI rice to meet the consumption needs of the entire population 
is indeed very small, but if specified for the poor population, the volume could be significant.

The location of the TTI mostly easy to find and to access as already stated in the selection indicator that TTI must be at strategic location and trader must had two years experiences was also an effort to make the consumers have easy access on TTI. In fact, all TTIC and TTID as well as most TTI were located in strategic location in the main road, while most TTI were located in traditional market area that is easy to find. Even the TTIC in West Java and some TTI just located beside rice store in traditional market. Once consumers known the availability of TTI rice, they will come back again to buy the rice because of the cheap prices and good quality. The TTI were often crowded of consumers, therefore to anticipate the jostle it was found some TTI gave a numbered card to queue up for the rice in maximum volume which have been decided. Beside in TTI, consumers also could buy rice in a certain moment such as a bazaar during Idul Fitri, Independence Day, certain occasion such as government celebration day as well as car free day and during market operation. In some cases, for example for the orphanage and dhuafa foundations or Pesantren more volume were permitted to access.

Effort to provide easy access on rice has also been done through online system (E-commerce), but problems have been encountered because not all LUPM leaders have mobile phones that can access the program, even if there are those who have access but cannot operate. Another obstacle is that through E-commerce to purchases the rice must paid in cash and in certain volume to make transportation costs efficient. This E-comerce system is finally accessed only by consumers who have enough money, and most probably bought by collectors or even an agent. If this is true, than the TTI price is imposible sold as TTI price. So once again it needs to be questioned, who is the TTI rice actually for, therefore it is necessary to determine the criteria for TTI rice consumers.

\section{TTI Development Strategy and Policy through Improvement of TTI Design and Implementation}

The TTI program had definitely success in shortening the supply chain, however as the result showed that the contribution of supply from TTI still could not influence the stabilization of supply and market price and consumers had no easy access yet to have TTI rice. This fact means that the internal management of actors in TTI supply chain should be improved.

Based on the reasons for consumers could not had easy access in having the TTI rice such as the volume were to low and no criteria for the consumers therefore to overcome theseproblem the TTI should provide more TTI number in wider areas with more volume and design the criteria for the consumer. If for some reason the increasing of the TTI number could not be implemented, it is suggested that the TTI rice only sold for special consumer namely the poor hausehold, the dhuafa or and orphan foundation . Through this policy, the TTI will have a dual impact, namely shortening the supply chain and overcoming the poverty to help the government effort in poverty alleviation which is consider an important program in the national developement.
The fact that the reasons of TTI had no effect yet on the supply and price stabilization were the limited contribution of rice and no obligation to LUPM to send the rice to TTI periodically therefore the policy to maintain the supply and price stability is by increasing the proportion of the rice volume from LUPM, and obligate to LUPM to supply rice to TTI in a continuous manner with a certain frequency in a year.

Based on the results that even the price of TTI rice were increased in similar trend with market price during 2018 which is caused by the increasing price of the grain and the low rendemen that only 52-53 percent (Table III) had made the majority of LUPM experienced of lossed in capital funds.

TABLE III. COMPENSATION COSTS SCENARIO

\begin{tabular}{|c|c|c|c|c|}
\hline Year & $\begin{array}{c}\text { Purchase } \\
\text { price GKP } \\
(\mathrm{IDR} / \mathrm{kg}) \\
1)\end{array}$ & $\begin{array}{c}\text { Rendemen } \\
(\mathrm{GKP})(\%)\end{array}$ & $\begin{array}{c}\text { Selling from } \\
\text { LUPM to TTIC } \\
\text { (IDR/kg) }\end{array}$ & $\begin{array}{c}\text { Selling from TTIC } \\
\text { to consumen } \\
(\mathrm{IDR} / \mathrm{kg}) \\
2)\end{array}$ \\
\hline 2016 & $4.500-4.600$ & $57-58$ & - & 7.700 \\
\hline 2017 & $4.900-5.100$ & 58 & 8.450 & 8.800 \\
\hline
\end{tabular}

Refer to the finding of capital funds losses and Table III it is important to create a scenario of funding compensation in order LUPM can continue to sell rice to TTI at IDR $8,500 / \mathrm{kg}$, the calculation simulation is presented in Table IV. Refer to the above scenario, a compensation fee of IDR $1,877 / \mathrm{kg}$ is needed so that additional operational costs of IDR $677 / \mathrm{kg}$ are needed, while for the scenario the price of GKP IDR 4,168/kg and IDR 4,000/kg compensation costs are no longer needed because the cost of processing and marketing rice to the market is the same or lower than the selling price to TTI. Otherwise the fund capital will run out or leftover and there will be no independent LUPM that means the goals of PUPM could not be achieved.

TABLE IV. COMPENSATION COSTS SCENARIO

\begin{tabular}{|l|r|r|r|r|}
\hline \multicolumn{1}{|c|}{ Criteria } & \multicolumn{4}{|c|}{ Price Scenario (GKP) } \\
\hline Price (GKP) & 5200.00 & 4828.00 & 4168.00 & 4000.00 \\
\hline $\begin{array}{l}\text { Rende- } \\
\text { men }= \\
55 \%\end{array}$ & 9454.55 & 8778.18 & 7.578 .18 & 7272.73 \\
\hline Drying & 150.00 & 15000 & 15000 & 150.00 \\
\hline Milling & 30000 & 30000 & 30000 & 300.00 \\
\hline Packing & 500.00 & 500,00 & 500,00 & 500.00 \\
\hline Transport & 225.00 & 22500 & 22500 & 22500 \\
\hline Total cost & 10629.55 & 9953.18 & 8753.18 & 8447.73 \\
\hline Bran & 230,00 & 23000 & 23000 & 23000 \\
\hline Broken rice & 22.50 & 22.50 & 22.50 & 22.50 \\
\hline Total (1) & 10377.05 & 970068 & 850068 & 8195.23 \\
\hline $\begin{array}{l}\text { TTI price } \\
(2)\end{array}$ & 8500.00 & 8500.00 & 850000 & 8500.00 \\
\hline
\end{tabular}




\begin{tabular}{|c|r|r|r|r|}
\hline Criteria & \multicolumn{4}{|c|}{ Price Scenario (GKP) } \\
\hline $\begin{array}{c}\text { Compen- } \\
\text { sation fee } \\
(3=1-2)\end{array}$ & 1877,05 & 1200.68 & 0.68 & -304.77 \\
\hline $\begin{array}{c}\text { Opera- } \\
\text { sional } \\
\text { cost } \\
\text { assistance } \\
(4)\end{array}$ & 120000 & 120000 & 120000 & 120000 \\
\hline $\begin{array}{c}\text { Additional } \\
\text { operation } \\
\text { cost }\end{array}$ & 67.05 & 0.68 & - & - \\
$(5=3-4)$ & & & & \\
\hline
\end{tabular}

\section{ACKNOWLEDGMENT}

Special sincere thanks is dedicated to the research tim: Dr. Hermanto, Dr. Erma Suryani, and Juni Hestina, M.S. and the Indonesian Centre for Socio Economic and Policy Studies, for providing funds for this research.

\section{REFERENCES}

[1] Indonesian Ministry of Agriculture. Act. No.06/KPTS/KN.010/K/02/2016. The guideline of the general implementation of TTI Program. Kementerian Pertanian Republik Indonesia.tentang pedoman umum pengembangan usaha masyarakat. No.06/KPTS/KN.010/K/02/2016. 2016.

[2] Agency for food security. Guideline for technical Development of Social Food Activities. Badan Ketahanan Pangan. Petunjuk teknis kegiatan pengembangan usaha pangan masyarakat.2018.

[3] Priyono. Book on qualitative research method. Buku metode penelitian kualitatif. Zifatama. 2016.

[4] Central Bureau of Statistic. Trade distribution on rice commodity in Indonesia. Badan Pusat Statistik. Distribusi perdagangan komoditas beras Indonesia. 2016.

[5] Iwan Setiajie., Hermanto., Erma Suryani., Sri Wahyuni dan Juni Hestina. Design dan implementasi TTI Design and implementation of TTI in effort to handle staple food strategies. Design dan implementasi TTI dalam upaya pengendalian harga pangan pokok dan strategis. Laporan akhir. Pusat Sosial Ekonomi dan Kebijakan Pertanian. 2018.

[6] Food security office of Special capital city of Jakarta. Rice Subsidy Program. Dinas Ketahanan Pangan Daerah Khusus Ibu kota Jakarta. Program-program subsidi beras di DKI. 2018.

[7] Indonesian Dictionary. Definition of efisiency. Kamus Besar Bahasa Indonesia. Pengertian kata efisien. kbbi.web.id/efisiens. 2018. 